\title{
„Nálunk (...) minden ötödik órában elhagyja az országot egy orvos"
}

\section{"A doctor leaves the country every five hours"}

\section{PITÓ KLÁRA}

PITó Klára: doktorjelölt, Budapesti Corvinus Egyetem, Szociológia Doktori Iskola; piklara@yahoo.co.uk

KULCSSZAVAK: nemzetközi migráció, migrációs potenciál, egészségügyi dolgozók, erdélyi magyar

ABSZTRAKT: A globalizáció következtében a magasan képzettek nemzetközi vándorlása - a munkaerőhiány miatt - egyre növekvő fontosságra tesz szert a kormányzati és nemzetközi migrációs és munkaerő-piaci politikákban. Az egészségügyi dolgozók migrációja különös figyelmet kap, mivel hiányuk kihat a lakosság egészségi állapotára, közvetve pedig befolyásolja annak gazdasági teljesítőképességét. Intézményi szinten megjelent a szakember-menedzselés tervezésének igénye, viszont megvalósítását az adathiány ellehetetleníti. Az EU különböző kutatási projektek révén törekszik a migráció nagyságának felbecsülésére az egyes tagországokban. Ehhez kíván, jóllehet nagyon szerény mértékben, hozzájárulni a jelen kutatás. Erdélyi magyar orvos-, gyógyszerész- és végzős nővérképzős hallgatók körében vizsgáltam a migrációs potenciált, azaz a külföldi munkavállalás tervezésében szerepet játszó taszító és vonzó tényezőket, a kedvelt célországokat és a migráns kapcsolatok hatását.

A tanulmány az elméleti és módszertani háttér ismertetése után a migrációs potenciált befolyásoló tényezők szerepét három részben elemzi: a szociodemográfiai tényezők, a kulturális (idegennyelv-ismeret) és a társadalmi (migráns kapcsolatok) tőke, valamint a pszichikai tényezők (attitüdök) mentén. Röviden megvizsgálja a tisztított migrációs potenciált, illetve bemutatja a vándorlás ellenében ható faktorokat és a maradás feltételeit.

A végzős hallgatók nyers migrációs potenciálja magasnak mondható az erdélyi magyar felnőtt népességhez képest, de megegyezik az erdélyi magyar fiatalok külföldi munkavállalási szándékával (60\%). A szociodemográfiai tényezők kevésbé befolyásolják a migrációs terveket, lévén, hogy sok szempontból szelektált, viszonylag homogén népességről van szó. A migráció tervezését leginkább a migráns hálózatok, főként a migráns baráti kapcsolatok segítik elő, továbbá a pesszimista jövőkép és az élettel való elégedetlenség. A család és a szülőföld szeretete a legerősebb helyben tartó tényezők.

Klára PITÓ: doctoral candidate, Doctoral School of Sociology, Corvinus University of Budapest; piklara@yahoo.co.uk

KEYWORDS: international migration, migration potential, health professionals, Transylvanian Hungarian

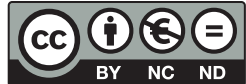


ABSTRACT: The international migration of professionals has become an increasingly important issue in this era of globalisation. Governmental policies related to international migration and the labour force have a varying impact depending on the nation in question. The international flow of health workers deserves a special focus due to their dwindling numbers in Hungary and Romania, a phenomenon which is in turn related to the economic achievements of a country (or the countries from where replacements are recruited).

Some institutions have demanded to plan for the management of human resources, but there was an obstacle in the lack of data. The EU tries to estimate the number of migrants in its member states through research projects. The research presented here aims to contribute to this work, although it covers only a small fraction of it. It examines the migration potential among Transylvanian-Hungarian students graduating in medicine, dentistry, pharmacology and nursing at the University of Medicine and Pharmacology of Tîrgu-Mureș, Romania. Using a selfcompletion questionnaire, the push and pull factors that affect decision-making, preferred countries of destination and the effects of migrant networks are explored.

This article presents, briefly, the theoretical background and the methodology. It then examines the factors affecting migration potential in three categories: socio-demographic, cultural capital (foreign language knowledge), and social capital (migrant network) and psychological factors (attitudes). It also reviews the proportion of a refined migration potential, as well as obstacles to moving and obligations causing those questioned to stay.

The migration potential among these students is high compared to that of the overall adult Transylvanian-Hungarian population and similar to the 17-30-year age bracket of young Transylvanian-Hungarians (about 60\%). The effects of socio-demographic factors are less significant due to the selected, homogeneous nature of the sample. The intention of migration is strengthened by migrant networks, particularly migrant friends, a pessimistic outlook on the future, and general dissatisfaction. Family responsibilities and love of country are the primary determinants for not migrating. The refined migration potential is also high: Two-thirds of students who intend to migrate (about 40 percent of the total student sample) have already taken steps in order to implement their migration plans. These include mainly gathering information from acquaintances and/or the internet and browsing job advertisements.

The main countries of destination are Germany, Great Britain, Hungary and Sweden. Hungary has been one of the most important countries of destination for Hungarian doctors in Transylvania because of historical links as well as cultural and linguistic similarities. The policies of the EU ensure the free movement of people across member states and recognition of medical diplomas acquired in any of them. They facilitate the trend of potential migrants actually moving to Western-European countries where the remuneration of their skills is much higher.

To better understand their thoughts about migration - their motivations, expected gains and disadvantages - and the role of ethnicity, some of these students were interviewed. Some results of this research were published in a separate article in another journal.

\section{Bevezetés}

Az orvosok és más egészségügyi dolgozók nemzetközi vándorlása korunk jelentős társadalmi kérdése és problémája. A nemzetközi migráció olyan sajátos formájával állunk szemben, amely növekvő fontosságú a kormányzati és nemzetközi migrációs, egészségügyi és munkaerő-piaci politikákban, a szociológiai és az interdiszciplináris migrációs kutatásokban, illetve a médiában megjelenő diskurzusokban.

A figyelem középpontjába kerülése számos, egymásra épülő tényezőnek köszönhető. A nemzetközi migráció növekvő volumenével és kétirányú hatása- 
ival egyre több kutató és döntéshozó érdeklődését keltette fel az elmúlt évtizedekben (Kaelin 2011; Lahav, Lavenex 2013; Levatino, Pecoud 2012). Ennek köszönhetően a migrációs szakirodalom jelentősen gazdagodott. Másodsorban a jóléti államok ambivalens bevándorlási politikái szintén figyelemfelkeltő szerepet játszottak és játszanak: míg a társadalmi és kulturális integráció megőrzése érdekében szigorú kontrollt gyakorolnak határaik felett, addig munkaerő-keresletük kielégítésére törekedve (a képzési költségek befektetése nélkül), továbbá bizonyos érdekcsoportok nyomására megkülönböztetett bánásmódban részesítik a munkamegosztási létra alján (szakképzetlen munkaerő) és csúcsán (magasan képzett vagy szakértői réteg) levőket (de Haas 2011; Lavenex 2008; Levatino, Pecoud 2012). Végül a téma aktualitását az egészségügyi rendszer súlyos szakemberhiánya, illetve a szakemberek globális, láncszerü vándorlása is indokolja (Greco 2010; Jenkins et al. 2010). A fejlődő országokban tapasztalható súlyos szakemberhiány és a fejlett országokból érkező erős szívó hatás (toborzás) arra enged következtetni, hogy az egyenlőtlenség a gazdaságilag fejlett és fejlődő országok között tovább mélyül (Cehan, Teodorescu 2012; Kaelin 2011). Az egészségügyi dolgozók vándorlásának egyedi jelentősége abban áll más foglalkozási csoportokhoz képest, hogy kihat nemcsak a lakosság egészségi állapotára, hanem közvetve befolyásolja annak gazdasági teljesítőképességét és életminőségét is (Eke, Girasek, Szócska 2009; Greco 2010). A toborzás etikusságát megkérdőjelező szakértők félelme főként azon alapul, hogy az alacsony és közepes jövedelmü országok amúgy is törékeny egészségügyi rendszerét tovább gyengíti, illetve fenntarthatóságukat veszélyezteti az egészségügyi dolgozók tömeges migrációja (Jakab 2011; Jenkins et al. 2010).

\section{Fontosabb migrációs elméletek}

A migrációs szakirodalom szerteágazó és sokrétű. A nemzetközi vándorlás folyamatainak időbeli fejlődésével és változásaival párhuzamosan különböző elméletek próbálták a mozgások kialakulásának, illetve fennmaradásának szegmenseit leírni és magyarázni (Massey 1999). Két elméleti megközelítés dominál a migráció kialakulásának magyarázatában: a közgazdaságtani és a történelmistrukturális irányzat. A neoklasszikus közgazdaságtan makro- és mikroszintű elméleteinek középpontjában a különböző országok eltérő szintű gazdasági fejlettsége, az ebből következő bérkülönbségek, valamint az ezekre reagáló, önös érdekeiket követő, haszonmaximalizáló egyének állnak. Ezekből a modellekből kiindulva alakultak ki a húzó-taszító elméletek, amelyek népszerűvé váltak a migrációs kutatásokban. A taszító tényezők a származási ország hiányosságaiból (pl. kedvezőtlen gazdasági és társadalmi feltételek) erednek, míg a húzóerőt a fejlettebb célországokban a várt és ténylegesen elérhető nyereségek jelentik (Messina, Lahav 2006; Portes 1995). Az új közgazdaságtan munkaerő-migrációs 
elmélete javított a neoklasszikus modell hiányosságain azáltal, hogy felismerte: a migráció általában egy többszemélyes döntés eredményeképpen jön létre, egy adott család, háztartás vagy tágabb közösség azon igyekezetéből, hogy a helyi piacok hiányosságaiból származó kockázatot csökkentsék a „több lábon állással" (Massey 1999; Roberts 1995). Ez a modell rámutat arra, hogy a kibocsátó társadalom tagjai között fennálló és növekvő jövedelmi különbségek és az ebből származó relatív depriváció is migrációt válthat ki (Massey 1999; Massey, Arango, Hugo, Kouaouci, Pellegrino, Taylor 1993). Ezzel szemben a történelmi-strukturalista megközelítés a migráció folyamatát tágabb keretben szemléli, hangsúlyozva a döntés kontextusát. A globális, makroszintű folyamatokra fókuszálva elsősorban a külső, strukturális erők irányítják a migrációs áramlatokat (Portes, Böröcz 2001).

Jelen kutatás szempontjából releváns és fontos még a migráns hálózatok elmélete. A migrációs irodalom különböző visszacsatolási mechanizmusokat tárt fel, amelyek magyarázatul szolgálnak arra, hogy a migráció, ha egyszer kezdetét veszi, miért válik önfenntartó folyamattá, migráns hálózatok és migrációs rendszerek kialakulásához vezetve. Ezek a visszaható mechanizmusok jól szemléltetik az egyéni döntések és a struktúra kölcsönhatását. A migráns hálózatok társadalmi tőkeként működnek az egyén és a csoport számára (Massey 1999; Portes 1995), gyakran a családi kapcsolatok biztosítják mindazt a pénzügyi, kulturális és társadalmi tőkét, amelyek lehetségessé teszik a migrációt (Castles, Miller 2009; Tilly 2001). Magyarországon az erdélyi magyar bevándorlók körében végzett kutatás arra a következtetésre jutott, hogy míg az idősek körében elsősorban az erős kötések (család, rokonság), a fiatalok körében a gyenge kötések (barátok) jelentik a migráns kapcsolati tőke fő forrásait (Gödri 2010). A nagy távolságokat átívelő baráti kapcsolatok, a családi láncok, az ezeken keresztül áramló új információk és az általuk kiváltott érdeklődés legalább annyira fontos a visszatérő migrációs mintában, mint a gazdasági nyereség fenntartása (Portes, Böröcz 1989; Sassen 1995).

\section{Egészségügyi dolgozók migrációja}

Magyarországon mindinkább érzékelhetővé válik az egészségügyi személyzet hiánya. Ennek fó okai a szakma rossz presztízse, ami alacsony beiskolázási számokban ölt testet; illetve a szakszemélyzet elvándorlása, melyet a hazai bérezéssel, továbbképzési lehetőségekkel, szakmai lehetőségekkel és az életminőséggel való elégedetlenség generál (Baukó et al. 2003; Vízvári 2003). A magyarországi orvosok elvándorlását 2003-tól elemzik a Semmelweis Egyetem Egészségügyi Menedzserképző Központ munkatársai. Egy 2008-ban végzett kérdőíves felmérésükből kiderül, hogy a magyar rezidens orvosoknak közel kétharmada (65\%) tervezett külföldi munkavállalást, ${ }^{1}$ ám a hiányszakmák esetében (pl. aneszteziológus, ra- 
diológus, sebész, háziorvos) még magasabb ez az arány. A migrációt tervezők körében a legfontosabb motivációk között a magasabb bérek, a jobb szakmai lehetőségek és munkakörülmények szerepeltek (Eke, Girasek, Szócska 2009).

A magyar egészségügyben az orvoshiányt a rendszerváltást megelőző években is többnyire a határon túli magyar szakemberek pótolták. A bevándorolt orvosok többsége romániai, ukrajnai és jugoszláviai egyetemeken szerezte szakképesítését. 1989 és 1992 között a MOK (Magyar Orvosi Kamara) 1462 bevándorolt orvost regisztrált, amelynek 61\%-a (887 fó) Marosvásárhelyen szerezte diplomáját (Balázs 2003). A Marosvásárhelyi Orvosi és Gyógyszerészeti Egyetem (továbbiakban MOGYE) az ezredfordulót követő években is kulcsfontosságú szerepet töltött be az anyaország orvoshiányának csökkentésében: a 2005-ben honosított 190 oklevél fele (95) marosvásárhelyi volt (Ábrám 2011).

Ami a szakdolgozókat illeti, Balogh Zoltán, a MESZK (Magyar Egészségügyi Szakdolgozói Kamara) elnökének közlései szerint az új évezred kezdetén, Románia uniós csatlakozását megelőző években évente kb. 200-250 ápoló vándorolt Magyarországra. Ez hiánypótló szerepet töltött be a magyar egészségügyben, ahol az ápolói létszámcsökkenés már megkezdődött. Megfigyelhető viszont a határon túli magyarlakta területekről érkező egészségügyi szakdolgozók számának csökkenése: bár 2007-ben még mindig Románia volt a legfontosabb kibocsátó ország Magyarország számára, de ez alig 50 főt jelentett, 2008-ban pedig ennél is kevesebbet (Balogh 2009).

Romániát az egészségügyi alkalmazottak migrációjáról ambivalens hozzáállás jellemzi. Diskurzus szintjén a román egészségügyi rendszer szakemberhiányát kommunikálják és javaslatokat fogalmaznak meg arra, hogy hogyan lehetne az orvosokat helyben maradásra bírni. ${ }^{2}$ Másfelől az állam mint a migrációt szervező aktor tevékenykedett az ország EU-csatlakozását megelőző években. A Munkaerő-migrációs Hivatal munkaerő-közvetítő szerepet töltött be: orvosokat és nővéreket toborzott, folyamatosan tájékoztatta az érdeklődőket a különböző országokban felmerülő keresletről, a hiányszakmákról, a bérekről, a munkaügyi törvényekről, a munkavállaláshoz szükséges dokumentumokról. Az uniós csatlakozás magával hozta az orvosi oklevelek kölcsönös elismerését, aminek eredményeképpen megnövekedett az orvosok külföldi munkavállalási hajlandósága (Rohova 2011). Romániában a csatlakozás évében 4990 fó igényelte a külföldi munkavállaláshoz szükséges igazolást, amely az egészségügyi dolgozók 10\%-át teszi ki. 2008. január-március közötti időszakban további 2683 fő váltotta ki a dokumentumot. Egy empirikus kutatás ugyan kimutatta, hogy 2007-ben a 4990 dolgozóból 1421 (a munkaerő 3\%-a) volt, aki ténylegesen migrált, ez még mindig magas arány ahhoz képest, hogy több más tagállamban a migrációs potenciál - a megigényelt igazolások száma - többnyire három százalék alatti volt a csatlakozás évében (például Magyarország: 2,7\%; Litvánia: 2,7\%, Észtország: 6,5\% - 2005-ben csak 1,8\%) (Maier et al. 2011).

Az Európai Unióban nemcsak egyes tagállamok küzdenek az elvándorlás következtében súlyosbodó munkaerőhiánnyal, hanem regionális szinten is nagy 
a hiány. A WHO becslései szerint 2020-ra az EU-ban egymillió fős lesz az egészségügyi dolgozók hiánya. E kihívás orvoslásához minden szereplő - a politikai vezetők, az egészségügyi szakértők és a civil társadalom - együttmüködésére van szükség. A szakembermenedzselés és -tervezés megvalósításában az egyik legnagyobb gondot az adathiány okozza, amely miatt a feladat jóformán teljesíthetetlen (Coggi 2011). Mégis vannak uniós szintű próbálkozások a migráció nagyságának felbecsülésére az egyes tagországokban a munkaerő tervezése céljából, amelyek hosszú távon keresik a megoldást a szakemberhiányra. A nemzetközi kutatások (mint az EU keretein belül megvalósuló WHO- és OECD-kezdeményezésű programok) elsősorban az egyes országokra koncentrálnak, így betekintést nyújtanak pl. a romániai egészségügyi szakmunkaerő migrációs folyamataiba, ${ }^{3}$ viszont nem tesznek különbséget az egyes országokban élő nemzetiségek között. Ily módon nem alkalmasak arra, hogy az erdélyi magyar egészségügyi dolgozók vándorlását megismerjük belőlük. ${ }^{4}$ Jelen kutatás ebben kíván hiánypótló szerepet betölteni. ${ }^{5}$

\section{A kutatás kérdései, az alkalmazott módszerek és a minta}

A kutatás fő kérdései a következők voltak: Mekkora a migrációs potenciál az erdélyi magyar végzős orvos-, gyógyszerész- és nővérképzős hallgatók körében? Kik a potenciális migránsok? Miért vándorolnának el, és mi az, ami otthon tartja őket, illetve milyen feltételek megváltoztatása révén lehetne maradásra bírni őket? Melyek a választott célországaik, és tagjaik-e azok irányába mutató hálózatoknak? Mikorra tervezik a külföldi munkavállalást, illetve hogyan hatnak a vándorlási szándékokra a különböző társadalmi-demográfiai és pszichikai (attitűd)tényezők?

Migrációs potenciál alatt a hallgatók külföldi munkavállalási szándékát értem. A nyers migrációs potenciál ezeket a szándékokat, migrációs terveket jelenti; a tisztított migrációs potenciál pedig a tervek megvalósítása érdekében tett beruházásokat is figyelembe véve méri a szándék komolyságát (Sik 2003). Értelemszerüen a migrációs szándék és a tényleges migráció közötti kapcsolat esetleges, de valószínűleg nagyobb arányban mozdulnak azok, akik tervezik azt. A migrációs tervek realizálódása a vándorlás során konvertálható speciális tőkék meglététől függ, amely tőkék a társadalmon belül egyenlőtlenül oszlanak el (Kiss, Csata 2004). Annak hátterében, hogy miért is foglalkozik a migrációs irodalom a potenciál mérésével, az a felfogás áll, hogy a migrációs szándékok olyan, figyelemre érdemes társadalmi tények, amelyek egy társadalmi csoport szociálpszichológiai állapotáról és a megkérdezettek cselekvési stratégiáiról nyújtanak információt (Gödri, Kiss 2009).

A jelenség sokoldalúságának megragadására ötvöztem a kvantitatív és kvalitatív módszereket. Jelen tanulmány mindössze a surveykutatás fontosabb eredményeit ismerteti, kereszttáblák elemzésével. Az adatfelvétel standardi- 
zált, önkitöltős kérdőívekkel történt 2012 novemberében és 2013 januárjában. Erdélyben egyetlen orvosi egyetemen, Marosvásárhelyen van magyar nyelvű képzés, itt az előadások magyarul, a gyakorlati órák román nyelven folynak. ${ }^{6}$ Ezért a kutatáshoz az alapsokaságot a MOGYE alapszakjain - általános orvos, fogorvos, gyógyszerész és nővér - tanuló, végzős hallgatók képezték. Kétségkívül más erdélyi orvosi egyetemeknek is vannak magyar hallgatói, de Magyarország számára a fó orvoskibocsátó intézmény a MOGYE. Mivel az egyetem nővérképzése kevés hallgatóval működik (30-35 fö évfolyamonként és nyelvi tagozatonként), továbbá Erdély több főiskolája is nyújt magyar nyelvű nővérképzést, ezért a nővéri almintát két másik intézmény végzős hallgatóival egészítettem ki. Egyikük a marosvásárhelyi Bod Péter Asszisztensképző Főiskola, a másik a csíkszeredai Louis Pasteur Egészségügyi Posztlíceum. Bár valamennyi intézmény vonzáskörzete nagy, az egyetem által nyújtott nővérképzés elsősorban a tanulmányi idő hosszában tér el a foiskolai képzéstől: előbbiben (2010 óta) négyéves, utóbbiban hároméves a képzés. Az orvosi karokon hat év, a gyógyszerészhallgatók számára pedig öt év a képzés időtartama.

Az adatfelvétel során a teljes sokaság lekérdezésére törekedtem; a megvalósult válaszadási arányok a következők: a MOGYE-n 73\%, a Bod Péter Asszisztensképző Főiskolán 58\%, a Louis Pasteur Egészségügyi Posztlíceumban pedig 85\%; összesen 251 fö. A férfiak és az idősebbek (a 25 év felettiek) kissé alulreprezentáltak a mintában, ezért szakonként nemek és korcsoportok szerinti súlyozással történt az elemzés. ${ }^{7}$

A kutatás korlátai a következők. A felmérés az erdélyi magyar egészségügyi szakember-utánpótlás migrációs potenciálját vizsgálta, de kérdéses, hogy a kapott eredmények mennyiben általánosíthatók egész Erdélyre. Másik problémaforrás lehet a nővérképző intézmények kiválasztásából származó torzítás, hiszen magyar nyelvű nővérképzés több más városban is folyik, illetve nem áll rendelkezésre adat arról, hogy hány magyar asszisztens végez román tannyelvü intézményben vagy csoportban. Az idősebb és az előadásokról hiányzó hallgatók nagyobb arányban maradtak ki a mintából, mint fiatalabb évfolyamtársaik, pedig ezek a tényezők szignifikáns különbségeket rejthetnek. Végül az eredmények alapján nem adható válasz arra a kérdésre, hogy a magyar egészségügyi rendszerben levő munkaerőhiány pótlását (szakterületenként, földrajzi régiónként) vagy az egyenlőtlenségek növelését eredményezné-e a tervezett migráció megvalósulása.

\section{A nyers migrációs potenciál}

A nyers migrációs potenciált a „Tervezed-e, hogy külföldön dolgozol?” kérdésre adott válaszokkal mértem, amelyet az 1. táblázat tartalmaz.

A hallgatók többsége tervezi a külföldi munkavállalást, csupán hat százalék zárja azt ki teljesen, illetve összesen egynegyede nem tervezi (a biztosan nem és 
1. táblázat: Külföldi munkavállalás tervezése (relatív megoszlások) Intention of being employed abroad (\%)

\begin{tabular}{lr}
\hline Biztosan nem & 6 \\
Kevéssé valószínű & 20 \\
Igen, de előbb itthon próbálkozom & 27 \\
Nagyon valószínű & 16 \\
Biztosan igen & 16 \\
Még nem döntött & 15 \\
\hline Összesen $(N=251)$ & 100 \\
\hline
\end{tabular}

nem valószínű válaszlehetőségeket, illetve a nagyon valószínű és biztosan igen kategóriákat az elemzésben összevontam). A külföldön munkát vállalni szándékozók aránya jóval magasabb, mint amekkora általában az erdélyi magyar felnőtt népességben: a kolozsvári Nemzeti Kisebbségkutató Intézet 2013 nyarán végzett reprezentatív kutatása szerint az erdélyi magyar felnőtt lakosság körében a külföldi munkavállalási potenciál 26\%-os, míg az elvándorlásé 10\% (NKI 2013). A különbség részben nem meglepő, hiszen az életkor növekedésével csökken a migrációs hajlandóság, vagyis a fiatalabbak inkább terveznek külföldre vándorlást (Örkény 2003). Amennyiben csak a fiatalok (17-30 évesek) külföldi munkavállalási szándékával hasonlítjuk össze az eredményeket, a különbség eltűnik: az erdélyi magyar fiataloknak közel háromötöde (58\%) tervez külföldi munkavállalást.

A magyarországi adatok tükrében magas a vizsgált sokaság migrációs potenciálja: a SOTE hallgatóinak ugyancsak egynegyede nem tervez külföldi munkavállalást diplomája megszerzése után, kétötöde viszont igen és 36 százaléka még bizonytalan terveiben. ${ }^{8}$ Ennél kissé magasabb a magyarországi rezidens orvosok migrációs hajlandósága, mintegy fele jelezte ezirányú szándékát; ${ }^{9}$ viszont ez utóbbi csoport már túljutott egy lehetséges elvándorlási szakaszon.

Az erdélyi és magyarországi hallgatói csoport adatainak összehasonlításából az a következtetés vonható le, hogy a magas migrációs potenciál kialakulásában a szakmai okok mellett olyan sajátos tényezők is szerepet játszhatnak, mint a globális hierarchiában elfoglalt hely (Melegh 2012) vagy a kisebbségi léthelyzet.

\section{Szociodemográfiai tényezők és azok hatásai}

Az erdélyi magyarok körében végzett migrációspotenciál-kutatások megállapították, hogy a vándorlási szándékot befolyásoló szociodemográfiai tényezők többek között a nem, az életkor, a családi állapot, a szubjektív vagyoni helyzet, az iskolai végzettség és a foglalkozás (jelen esetben: a hallgatott szak) (Gödri, Kiss 2009; Kiss, Csata 2004; Sik, Örkény 2003; Simonovits 2003). Mivel a vizsgált népesség bizonyos szempontból homogén (például végzettségében), illetve fiatal, e kérdések némelyike a szülőkre irányult. 
A korábbi felmérések eredményei alapján várhatóan a nők a férfiakhoz hasonló arányban tervezik a migrációt (a nemek szerinti eltérés a migráció típusában jellemző), míg a fiatalabbak, az egyedülállók vagy élettársi viszonyban élők inkább szándékoznak külföldön munkát vállalni. (Ezen belül különbségek vannak a migráció típusában és a célországokban.) Az eredmények alapján megállapítható, hogy a nemek között nincs lényeges eltérés a külföldi munkavállalás tervezésében, ami alátámasztja a korábbi megfigyeléseket (Örkény 2003; Tóth 2004). Jóllehet a férfiak nagyobb arányban vetik el a külföldi munka gondolatát, a nőkre a határozatlanság is sokkal inkább jellemző. Életkor szerint sincs szignifikáns eltérés, bár a fiatalabb korcsoport ( $\leq 24$ év) nagyobb arányban határozatlan és „próbálkozna előbb otthon”. Szignifikánsak a különbségek a családi állapot szerint: várakozásaimmal ellentétben a „nem együtt élő párkapcsolattal rendelkezők" tervezik leginkább a külföldi munkavállalást, legkevésbé pedig az együtt élók. A házasoknak - a hajadonokhoz-nőtlenekhez hasonlóan - több mint fele szándékszik külföldre menni; jóllehet a helyben maradás mellett is leginkább ők döntenek (chi-négyzet: 17,368; szignifikanciaszint: 0,043). ${ }^{10}$

A nővérek tervezik leginkább a migrációt (majdnem háromnegyedük), legkevésbé a gyógyszerészek. Az orvos- és fogorvoshallgatóknak mintegy fele szándékszik külföldre menni, viszont a fogorvosok inkább „előbb otthon próbálkoznának."11

A szülők iskolai végzettsége a korábbi megállapításokhoz híven - amelyek ugyan a válaszadó iskolai végzettségét vették alapul (Kiss, Csata 2004) - nem hat a külföldi munkavállalás tervezésére (57-64\% közöttiek az értékek), viszont eltérő stratégiákhoz vezet. (A magyarországi kutatás szerint a szülők iskolázottsági szintjével párhuzamosan növekszik a külföldi munkavállalási hajlandóság.) Az alacsonyabb szülői kulturális tőkével rendelkezők átlagon felül szándékoznak külföldön munkát vállalni, a középfokú (érettségi) iskolai végzettségü szülők gyerekei „előbb otthon próbálkoznának”, a legmagasabban iskolázottak gyerekei kissé nagyobb arányban tervezik a maradást. ${ }^{12}$ Hasonlóképpen a szülők foglalkozása sem hat szignifikánsan a vándorlási tervekre. A gazdaságilag inaktív, munkanélküli és elhunyt szülők gyermekei a legkevésbé, míg a vállalkozó, önálló és szabad szellemi foglalkozású apákéi és a kékgalléros (szak-, betanított és segédmunkás, gazdálkodó) anyákéi szándékoznak leginkább külföldön munkát vállalni. Úgy tünik, hogy részben szakmai vagy presztízsokok játszanak szerepet, vagyis a migráció a státuszmegőrzést szolgálhatja; ugyanakkor a társadalmi és földrajzi mobilitás összekapcsolódása is megfigyelhetö. ${ }^{13}$

A családi státusz a szülők iskolai végzettségéből és foglalkozásából képzett index, melyben 3 kategóriát különböztettem meg: magasabb (magas iskolai végzettséggel párosuló diplomás, szellemi, vállalkozói vagy vezetői munkakör), alacsonyabb (alacsonyabb szülői iskolai végzettség és azzal párosuló kékgalléros, gazdálkodó, inaktív munka, beosztás) és vegyes (egyik szülő egyik, a másik szülő a másik kategóriába tartozik) státusz. ${ }^{14} \mathrm{~A}$ vegyes státuszúak kisebb arányban terveznek külföldön munkát vállalni. Elképzelésem szerint a háttérben a 
szülők iskolai végzettsége és foglalkozása vagy az apa és anya foglalkozása közötti diszkrepancia húzódik meg, amelyek akár egymás ellenében hathatnak a vegyes státusz esetében.

A szubjektív anyagi helyzet lényeges eleme a migrációs terveknek. Az, hogy milyennek észlelik anyagi helyzetüket, inkább meghatározó szándékaik befolyásolásában, mint az objektív anyagi helyzet (Demuth 2000). A szülők szubjektív anyagi helyzetét két skálán mértem: az egyik a „nélkülözések között élnek” és a „gondok nélkül élnek” közötti ötfokú skála, míg a másik a nagyon szegénytől a nagyon gazdagig terjedő tizenegy fokú skála volt. Az anyagi nehézségek megléte, illetve hiánya nem hat a helyben maradási vagy külföldi munkavállalási hajlandóságra, de a vagyonossági skálával már pontosabb képet kapunk. A fejlődési elmélet (a fejlődés kezdeti szakaszában nem csökken a migránsok száma, hanem növekszik, mivel ekkor már rendelkeznek a vándorlás megvalósításához szükséges eszközökkel - de Haas 2011) megállapításához hüen (Portes, Böröcz 2001) azt találjuk, hogy a közepes és a nagyon jó anyagi helyzettel bírók tervezik leginkább a külföldi munkát, bár a gazdagok majdnem a szegényekhez hasonló arányban vetik el a migráció tervét. Ez hasonló a magyarországi hallgatókhoz: körükben is az átlagosnál jobb anyagi helyzetben élők tervezik leginkább a munkavállalást, viszont az átlagosnál rosszabb anyagi körülmények között élők követik őket. A két alsó kategóriába tartozókra sokkal inkább jellemző a határozatlanság. ${ }^{15}$

\section{A külföldi munka tervezése}

\section{A kapcsolati tóke szerepe}

A kapcsolati tőke az egyént körülvevő személyes és tágabb kapcsolati hálót jelenti, amely az egyén migrációs döntését befolyásolja. Minél több olyan emberrel áll kapcsolatban a potenciális migráns, akik külföldön dolgoztak, dolgoznak vagy élnek, annál inkább nő a valószínűsége annak, hogy ő maga is a migráció mellett dönt (Tilly 2001). Jelen esetben a választott célországba mutató kapcsolatot vizsgáltam, és annak hatását a migrációs szándékokra.

A külföldi munkát fontolgatók felének nincs személyes kapcsolata a célországban élő vagy tartózkodó személlyel; ők kissé nagyobb arányban vetik el a külföldi munkavállalást. A végzősök negyedének él az adott országban rokona, hatoduknak barátja és minden kilencediknek ismerőse. Az érintett országokban élő barátok négyötöde magyar nemzetiségü, illetve erdélyi származású. Ez a migráns kapcsolatok erős beágyazottságára utal: a tagok zömében a kibocsátó közösségből származnak, viszont a kapcsolatok szélesednek, vagyis a kibocsátó és befogadó hálózatok összefonódnak (Tilly 2001). A külföldön élőkkel kapcso- 
latban állók több mint fele tapasztalt személyes toborzást külföldi munkavállalásra a rokonai, barátai részéről (Sassen 2007). Szoros összefüggés van a kapcsolat típusa és a migrációs tervek között. Leginkább egy barát jelenléte az adott országban vezet a külföldi munkavállalás tervezéséhez, de a rokon jelenléte is hasonló módon hat. Ez alátámasztja azt a korábbi megállapítást, hogy a migrációs szándékban a fiatalok számára fontosabb szerepet töltenek be a baráti, mint a rokonsági kapcsolatok (Gödri 2010; Gödri, Kiss 2009). A kapcsolatitőke-szegénység inkább a helyben maradás, illetve az „előbb otthon próbálkozás” tervezését erősíti. A kívülről érkező bátorítás is növeli a migrációs hajlandóságot.

A kapcsolati tőke fontossága nemcsak a migrációs szándékra gyakorolt hatásban mutatkozik meg, hanem információforrásként is fontos szerepet tölt be (Portes 1998; Sassen 1995). A külföldi munkavállalást előkészítő lépések közül első helyen áll a magyar hallgatók esetében a barátoktól, ismerősöktől való személyes érdeklődés (34\% említette), megelőzve az interneten gyüjtött információk említési gyakoriságát (18\%). (Több választ is meg lehetett jelölni.)

Az erdélyi magyarság körében mindig is népszerű Németország a legkedveltebb (Sik, Simonovits 2003). Magyarország vonzerejének csökkenése (Gödri, Kiss 2009) itt is tetten érhető: a harmadik helyet foglalja el Anglia után. ${ }^{16}$ Ennek okai között a magyar egészségügy átszervezése, a leépítések stb. szerepelhetnek, illetve a 2007 januárjától már a román állampolgárok részére is elérhető más országok munkaerőpiacainak komparatív előnyei. Magyarország leginkább a fogorvos szakra járók számára jelent célországot, 43\%-uk jelölte meg, így számukra az anyaország éppúgy az első helyen áll, mint Németország. Legkevésbé a nővérek készülnek Magyarországra (22\%), mivel - amint a már átvándoroltakkal készült interjúkból kiderül - részükre nem jelent hasznot az anyaországi munkavállalás. Nincs összefüggés a társadalmi státusz és a célország megválasztása között, tehát a korábbi kutatások eredményeire (Kiss 2012) alapozott feltételezésem, miszerint Magyarországot inkább az alacsony és vegyes státuszúak választják, nem igazolódott be. A későbbiekben készített interjúk (Pitó 2015) is megerősítik, hogy inkább a magas státusszal rendelkezők, a státuszmegőrzők említették Magyarországot. Ennek egyik fó oka a korábbi tanulmányi célú migrációs tapasztalat (részképzés), amely kiszélesítette a potenciális migráns referenciaterét és bővítette társadalmi tőkéjét. A másik fő ok a migráció motivációjában található: a Magyarországra vándorlókat szakmai továbbképzési vagy tapasztalatszerzési lehetőség vezérli inkább, mintsem a két ország közötti bérkülönbségek. Ezen felül szerepet játszanak a migráns hálózatok, a nyelvi azonosság (egy idegen szaknyelv ismeretének hiányosságai) és a párkapcsolat.

\section{A külföldi munkavállalás időzitése}

A külföldi munkavállalás időzítése összefügg a célországok népszerüségével (1. ábra). 
1. ábra: A leggyakrabban megjelölt célországok a migráció tervezett ideje függvényében Prefered distination countries geared to the planned timing of migration

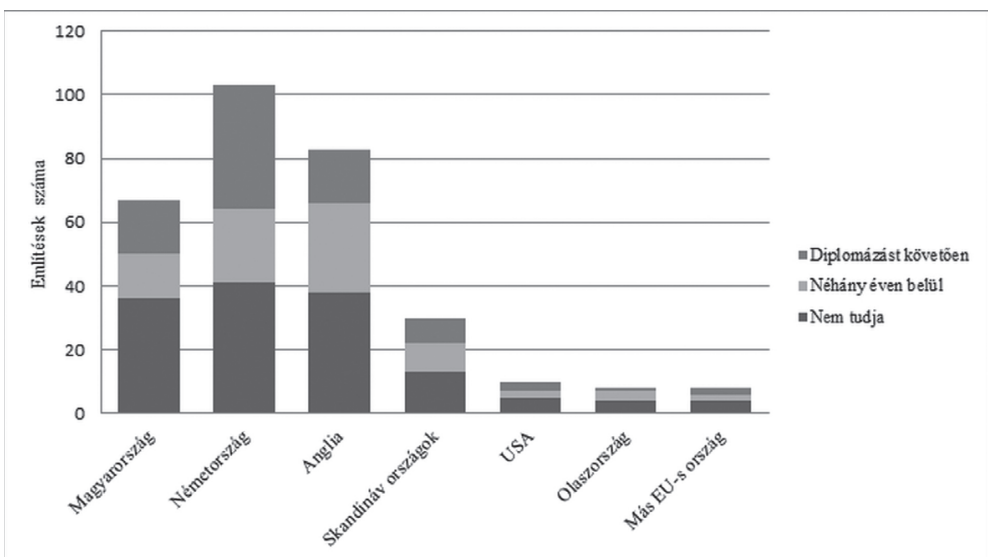

$N$ (összes emlités)= 309 (több válasz is megjelölhetö volt).

A célterület és a vándorlás tervezett időzítése közötti kapcsolat csak Németország esetében szignifikáns (chi-négyzet: 8,303; szignifikanciaszint: 0,016). A Németországot (is) választók körében a közvetlenül diplomázás utánra, a rezidensképzésre időzített vándorlást tervezők aránya megközelíti a határozatlanokét; ez utóbbi a legnagyobb hányad minden ország esetében (38\%, illetve 40\%). Ez azért fontos, mert az időben közeli és határozott migrációs tervek nagyobb valószínűséggel valósulnak meg, mint az idő távlatába vesző és bizonytalan tervek (Horváth 2003). Vagyis az amúgy is kedvelt Németországba valószínűleg nagyobb lesz a munkavállalás és szakképzés céljából megvalósuló migráció. A Magyarországot (is) választók több mint felének nincs konkrét terve arra, hogy mikor is szeretné a külföldi munkavállalást elkezdeni, egynegyede már rögtön diplomázás után elkezdené itt a munkavégzést, tanulást - ez a gyógyszerészek kivételével valamennyi szakot egyformán érinti.

\section{Idegennyelv-ismeret: az inkorporált kulturális tóke hatásai}

Az a korábban megfigyelt tendencia, hogy a magasabb idegennyelv-ismerettel bírók inkább Nyugat-Európa országaiba, a szegényes nyelvtudással rendelkezők pedig inkább Magyarországra szándékoznak menni (Kiss 2012; Örkény 2003), csak részben igaz a vizsgált népességre, vagy legalábbis nem különül el élesen egymástól a két csoport. ${ }^{17}$ A Magyarországot (is) célországként megjelölők fele alacsony szintű idegennyelvtudással rendelkezik és csak egyötödének van nyelvvizsga-bizonyítványa; de a Németországba igyekvőknél is hasonló a helyzet.

Szignifikáns azonban az idegen nyelvű média (folyóirat, napilap, rádió, TV) fogyasztása és a migráció tervezése közötti kapcsolat (chi-négyzet: 6,195; szignifikanciasazint: 0,013). Viszont az idegen nyelvü média fogyasztásának gyakorisága már 
nem függ össze szignifikánsan a migráció tervezésével; jóllehet a vándorlást tervezők gyakrabban néznek, hallgatnak, olvasnak külföldi médiát.

Úgy tűnik, a nyelvismeret olyan kulturális tőkeként működik, amely elősegítheti a külföldi munkavállalás megvalósítását, mivel szükség esetén bármikor mozgósítható.

\section{Az attitüdtényezők hatása}

\section{Helyzet- és jövókép}

A végzős hallgatók véleményét megkérdeztem helyzetüket és jövőjüket érintő kijelentésekről, amelyet ötfokú Likert-skálán jelölhettek meg ( 1 = egyáltalán nem ért egyet, 5 = teljesen egyetért). Az, hogy az egyén milyennek érzékeli és értékeli saját helyzetét és lehetőségeit, befolyásolja szándékait és jövőjét érintő döntéseit (Festinger 2000; Örkény 2003). Hat állítás közül kettő a tágabbi környezetre vonatkozott (romániai fiatalság és az erdélyi magyar kisebbség jövője), egy a nemek közötti megkülönböztetésre (külföldön több esélyük van a nőknek az orvosi pályán), három pedig a jövedelemre (a kezdő fizetés elégségessége, a hálapénz szükségessége és egy hipotetikus helyzet: itthon maradna-e a nyugati kereset feléért).

Leginkább azzal értettek egyet a hallgatók, hogy egészségügyi dolgozóként az ember nem képes eltartani családját a kezdő fizetéséből18 (átlag: 3,95), és szintén nagy volt az egyetértés abban, hogy a nyugat-európai orvosi, gyógyszerész, nővéri bérek feléért biztosan otthon maradnának (átlag: 3,80). A nőket nem látják hátrányos helyzetben az orvosi pályán külföldi kollégáikhoz képest (átlag: 2,15) és a nők maguk sem tartják magukat annak (átlag: 2,24); bár a pályaválasztásnál vagy a szakterület kiválasztásánál fontos szempont többek számára, hogy az összeegyeztethető legyen a női és anyaszereppel (a női orvostanhallgatók negyede említette ezt).

A nővérek ítélik meg leginkább kilátástalannak a jövőjüket Romániában élő fiatalokként (átlag: 3,56; F = 10,745; szignifikanciaszint: 0,000) és magyarokként, őket követik a fogorvoshallgatók. Leginkább az orvostan- és nővérhallgatók vélik úgy, hogy a kezdő fizetés nem elégséges a megélhetéshez, illetve a gyógyszerészek látják legkedvezőbbnek majdani bérezésüket. A hálapénz szükségességével leginkább az orvosok és legkevésbé a nővérek (szignifikanciaszint: $0,001)$ értettek egyet. Véleményük szerint többségüket a magasabb kereset biztosan otthon tartaná; kevésbé igaz ez a fogorvoshallgatókra.

Ezt támasztja alá a vándorlás motivációiként megjelölt tényezők rangsora. A kérdőívben szereplő hat motiváció közül a négy leggyakoribb a következő volt: a külföldön elérhető magasabb bérek (87\%), a jobb munkakörülmények 
2. táblázat: A jövőkép és a migráció kapcsolata

Effects of perception of future on intention of migration

\begin{tabular}{|c|c|c|c|}
\hline Egyetért az alábbi kijelentéssel & $\begin{array}{c}\text { Tervez külföldi } \\
\text { munkavállalást (\%) }\end{array}$ & \multicolumn{2}{|c|}{ Chi-négyzet Szignifikanciaszint } \\
\hline A fiataloknak nincs jövője az országban $(n=72)$ & 83 & 19,633 & 0,000 \\
\hline $\begin{array}{l}\text { A magyarok mindig hátrányos helyzetben } \\
\text { lesznek Romániában ( } n=108)\end{array}$ & 70 & 6,16 & 0,013 \\
\hline $\begin{array}{l}\text { Külföldön a nőknek nagyobb esélye van egyes } \\
\text { szakterületeken elhelyezkedni }(n=16)\end{array}$ & 63 & 0 & 0,992 \\
\hline $\begin{array}{l}\text { Kezdő orvosként (stb.) otthon az ember } \\
\text { képtelen eltartani a családját ( } \mathrm{n}=154)\end{array}$ & 78 & 17,266 & 0,000 \\
\hline A hálapénz szükséges rossz (n=100) & 71 & 0,363 & 0,547 \\
\hline $\begin{array}{l}\text { A nyugati fizetés feléért biztosan maradna } \\
(\mathrm{n}=128)\end{array}$ & 72 & 0,294 & 0,588 \\
\hline
\end{tabular}

Megjegyzés: Az egyet is ért, meg nem is válaszok nélkül.

(86\%), több lehetőség a szakmai fejlődésre (81\%) és a magasabb életszínvonal (76\%). A külföldön megszerezhető magasabb fizetés főként a fogorvos- és gyógyszerészhallgatók számára (chi-négyzet: 7,780; szignifikanciaszint: 0,051), a jobb munkakörülmények legkevésbé a gyógyszerészhallgatók, a több szakmai fejlődési lehetőség a fogorvos- és orvostanhallgatók számára motiváló. A magasabb életszínvonal és magasabb szakmai presztízs elsősorban a gyógyszerészek, míg a román nyelvi problémák főként a nővér- és kissé a fogorvoshallgatók számára jelentenek motivációt a külföldi munkavállalásra.

A 2. táblázatból látható, hogy azok a hallgatók, akik szülőhazájukban a jövőjüket fiatalként, kisebbségiként és/vagy pályakezdőként bizonytalannak gondolják, inkább tervezik a külföldi munkavállalást. Ez a kérdés nem alkalmas annak megválaszolására, hogy hogyan függnek össze ok-okozati szempontból az attitüdök és tervek, de véleményem szerint kölcsönhatás van közöttük: a kedvezőtlen jövőbeni kilátások nemcsak okai a migrációs tervek megszületésének, hanem e terveket alátámasztó legitimációs szociálpszichológiai tényezőkként is müködnek. Illetve megfordítva a dolgot: azok a tőkeszegényebb csoportok, akik úgy vélik, hogy nem változtathatják meg állapotukat, a belső konfliktus elkerülése végett megszépítik jövőképüket (Festinger 2000).

\section{Elégedettség}

Megvizsgáltam a hallgatók elégedettségét a kapott szakmai képzéssel és eddigi életükkel. Az első tényező esetében kíváncsi voltam arra, hogy a képzéssel való elégedetlenség - az inkompatibilitás érzését eredményezve - inkább gátolja-e a külföldi munkavállalás tervezését, vagy éppen ellenkezőleg, bátorítja azt, mintegy a szakmai innováció lehetőségével kecsegtetve a vándorlást tervezőt. Az elégedetlenség kissé erősítheti a külföldi munkavállalás szándékát: az elégedettek több mint fele 
tervezi a migrációt, míg az elégedetleneknek kétharmada. Ez az összefüggés viszont nem szignifikáns, még a bizonytalanok figyelembevétele nélkül sem.

Nagyobb elégedettséget találtam, amikor eddigi életükre kérdeztem rá. A tizenegy fokú skálán $(0=$ nagyon elégedetlen, 10 = teljesen elégedett) 7,31-es átlagot mértem. Az eddigi életükkel való elégedettséget leginkább a szülők kedvező anyagi helyzete befolyásolja. A szegényebb családból származók elégedettségi átlaga 6,60; a közepes anyagi helyzetüeké 7,42; míg a gazdagoké 7,83. Mivel mindkét tényező szubjektív megítélésen alapszik, a kettő közötti összefüggés igazolja és jól tükrözi a relatív depriváció és az elégedettség közötti kapcsolatot (Gödri, Kiss 2009).

Részben beigazolódni látszik Sik és Örkény megállapítása, mely szerint az elégedetlenség „a migrációs potenciál motorja” (Sik, Örkény 2003: 191). A relatív depriváció vagy az attól való félelem migrációs tervek megszületéséhez vezethet (Kiss, Csata 2004), de csak bizonyos mértékben. A nagyon elégedetlenek a legkisebb anyagi tőkével rendelkező családokból származnak, így bár a mobilitási szándék bennük is megvan, de nem rendelkeznek az ehhez szükséges erőforrásokkal, gazdasági tőkével. Másfelől viszont a nagymértékű elégedettség a helyben maradási szándékot erősíti (Sik, Örkény 2003).

\section{Tisztított migrációs potenciál}

A csak elméleti síkon, a tervek szintjén létező migrációs szándék kisebb mértékben valósul meg (Horváth 2003). A külföldi munkavállalást tervező 148 hallgatónak ${ }^{19}$ egyharmada (48fó) még csak gondolkodott a migráción, és a megkérdezés időpontjáig semmit nem tett szándéka megvalósítására. Ez részben magyarázható a migrációt később tervezők („előbb otthon próbálkozók”) jelentős hányadával (45\%). A külföldi munkavállalást tervező végzős hallgatóknak egyharmada a döntés fázisában van, és még nem lépett át a második szakaszba, amely a migrációhoz szükséges feltételek megteremtését jelenti (Horváth 2003). Ezt támasztja alá az is, hogy az időzítésben hasonló a határozatlanok aránya (37\%) a migrációt közvetlenül a diplomázás utánra tervezőkéhez (40\%). Tisztított migrációs potenciálnak tehát azt a 98 hallgatót tekintem (az összes hallgató 39\%-a), akik tettek már valamilyen lépést a külföldi munkavállalás érdekében. Ezeket a 3. táblázat foglalja össze.

Amint arra már utaltam, a személyes kapcsolatok fontos információs csatornákként is müködnek, de azt, hogy milyen más források állnak rendelkezésre, illetve melyeket vett vagy venne igénybe a potenciális migráns, külön kérdéssel vizsgáltam. A személyes kapcsolatok révén való informálódást az internetről való tájékozódás követi; nagyszámban (64 hallgató említette) vennék igénybe munkaerő-közvetítő iroda segítségét, illetve a levelezőlistára érkező e-mailekből is tájékozódhat, értesülhet álláshirdetésekről a potenciális munkavállaló. 
3. táblázat: Megtett lépések a migrációs terv megvalósítására (\%) Steps taken in order to realize migratory plans

\begin{tabular}{lr}
\hline Személyes kapcsolatain keresztül érdeklődött & 47 \\
Interneten gyüjtött információkat & 23 \\
Konkrét álláshirdetéseket nézegetett & 16 \\
Személyesen körülnézett külföldön & 5 \\
Elkezdte tanulni a nyelvet & 3 \\
Jelentkezett állásra, interjúra megy & 1 \\
Egyéb & 5 \\
\hline Összesen $(N=148)$ & 100 \\
\hline
\end{tabular}

Megjegyzés: Több válaszlehetöség is megjelölhetö volt.

\section{Ellenmotivációk, helyben tartó tényezők}

A hazához, szülőföldhöz való kötődés a második leggyakrabban említett visszatartó erő. Míg az ezredforduló környékén az erdélyi magyar társadalom tagjai számára a szülőföldön maradás volt a legfontosabb visszatartó tényező, idővel fokozatosan a család vette át ennek a helyét (Gödri, Kiss 2009). Ez a „mi” közösség sorvadására utal (Sik, Örkény 2003). A sorban harmadik helyet elfoglaló „otthon is meg lehet élni és közel vannak azok, akiket szeretek” válaszlehetőség értelmezhető úgy, mint a család és szülőföld együttes választása. Mivel ebben a kijelentésben legalább annyira hangsúlyos a család, mint a szülőföld szerepe, ezért nem vélem úgy, hogy ez változtatna a család és a szülőföld fontossági sorrendjén.

A szülőföld iránti szeretet és a kisebbségi magyarok iránt érzett kollektív felelősségtudat leginkább az orvostan- és fogorvoshallgatók számára jelent visszatartó tényezőt. A fogorvos- és gyógyszerészhallgatók némelyikének van már állása (vagy legalábbis állásígérete) otthon. A család, értelemszerủen, legfőképpen a házasok esetében jelenik meg visszatartó erőként. Megfigyelhető, hogy a szülőföldhöz ragaszkodók inkább választják Magyarországot, ami utalhat arra, hogy ideológiailag a kettő (azaz Erdély és Magyarország) összetartozik számukra: ${ }^{20}$ vagy lehet ennek egy másik, a földrajzi közelséggel magyarázható oka is.

A neoklasszikus közgazdaságtan mikroelmélete szerint a migrációs döntés az egyén költség-haszon elemzésén alapszik (Castles, Miller 2009; Massey, Arango, Hugo, Kouaouci, Pellegrino, Taylor 1993; Portes 1995). Valójában a döntés mechanizmusa és a számításba vett vagy nem tudatos, ám a döntést befolyásoló tényezők ennél jóval összetettebbek, de kétségkívül a haszon (akár gazdasági, akár társadalmi, akár pszichikai) mérlegelése is szerepet játszik.

A három leggyakrabban említett, otthon maradásra késztető tényező (2. ábra) megegyezik a magyarországi rezidens orvosok és a romániai orvosok körében tapasztalható motivációkkal (Eke, Girasek, Szócska 2009; Glinos, Wismar, Maier, Palm, Figueras 2011). A nagyobb fizetés fóként az orvosokat, 
2. ábra: A maradás feltételeiként leggyakrabban megnevezett tényezők

Factors mentioned as stipulations of staying at home

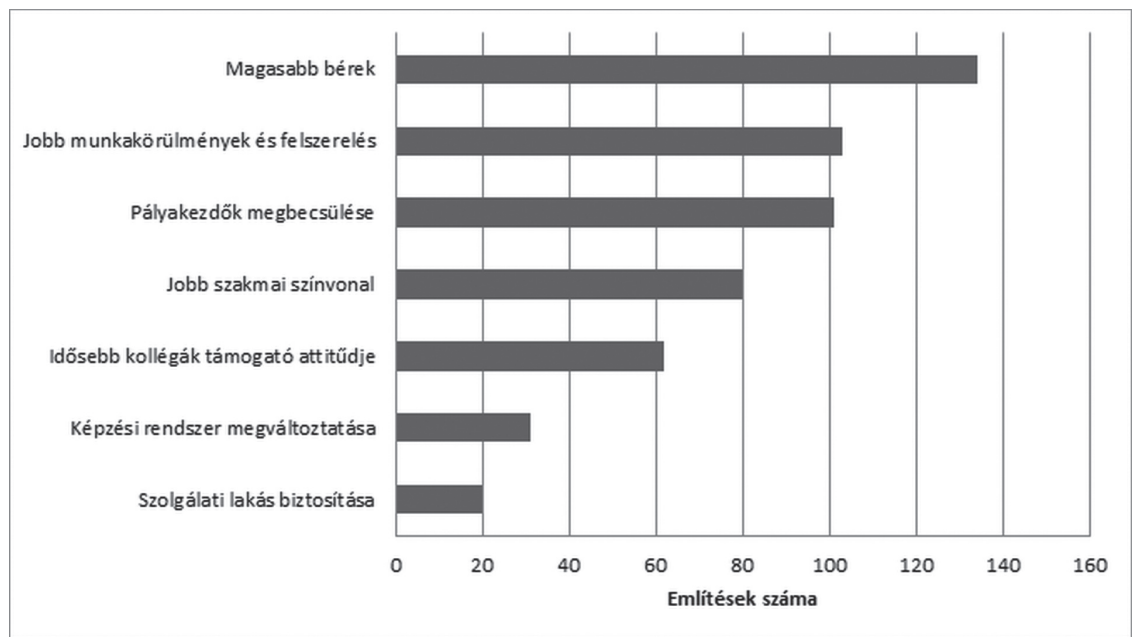

$N($ összes említés $)=502$.

nővéreket és gyógyszerészeket ösztönözné maradásra, a jobb munkakörülmények és felszerelés biztosítása valamennyiük számára feltétel, míg a nagyobb megbecsültség főként a nővéreknél bizonyulna hatásos eszköznek az otthon maradásra bírás érdekében. A vágyott bérek szakonként a következők: legmagasabb fizetést a gyógyszerészhallgatók neveztek meg, a mediánérték 4000 RON (kb. $900 €$ ), az orvostanhallgatóknál 2500 RON (kb. $580 €$ ), a fogorvoshallgatóknál 2100 RON (kb. $480 €$ ), a nővéreknél pedig 1500 RON (kb. $350 €$ ); azaz ekkora (kezdő) fizetésért volnának hajlandók az országban maradni. A szakmai színvonal javítását egyharmaduk, az idősebb kollégák támogató attitűdjét egynegyedük említette. A magasabb szakmai színvonal biztosítása főként a fogorvos- és gyógyszerészhallgatók, a szakmabeliek attitűdjének megváltozása pedig az orvostan- és fogorvoshallgatók esetében erősítené a helyben maradást.

\section{Összegzés}

A vizsgált erdélyi végzős orvostan-, fogorvos-, gyógyszerész- és nővérhallgatók háromötöde tervez külföldi munkavállalást. Ezt a szándékot a szociodemográfiai tényezők nem befolyásolják számottevően, bár egy kétpólusú, statisztikailag nem szignifikáns tendencia látszik kirajzolódni. A nemzetközi vándorláshoz kettős elvárás füződik: az alacsonyabb státuszúak számára a társadalmi mobilitás, a magasabb státuszúaknak pedig a státuszmegőrzés eszközét jelenti (Glick Schiller, Basch, Szanton Blanc 1995; Gödri 2010). 
Fontos szerepet töltenek be a baráti migráns kapcsolatok, amelyek főként a kibocsátó társadalomba ágyazottak, elsődleges információforrássá váltak és egyben a személyes toborzás csatornáivá is (Portes 1998; Sassen 2007). Magyarország a szívóhatását elsősorban a migráns hálózatoknak, a romániaitól eltérő szakmai képzési rendszerének és felszereltségének, valamint a nyelvi azonosságnak köszönheti (vö. Pitó 2015).

A külföldi munkavállalásra leginkább ösztönző tényezők a külföldön elérhető magasabb bérek, a jobb munkakörülmények és felszerelés, valamint a szakmai fejlődésre való több lehetőség. Ugyanezek a legfontosabb vándorlásra motiváló tényezők a magyar és a román egészségügyi dolgozók esetében is (Eke, Girasek, Szócska 2011; Rohova 2011).

Fontos lenne ezen megállapítások érvényességét nagyobb mintán is tesztelni, hiszen a szakember-menedzseléshez nagy populációt leíró adatokra van szükség. Hasznos lenne továbbá a vizsgált hallgatók újbóli megkeresése egy panelvizsgálat keretében, amely lehetőséget nyújtana a tervek realizálódásának mérésére.

\section{Köszönetnyilvánítás}

Köszönet az Educatio Társadalmi Szolgáltató Nonprofit Kft.-nek, valamint a kolozsvári Nemzeti Kisebbségkutató Intézetnek, hogy rendelkezésemre bocsátották az összehasonlítás alapjául szolgáló adatbázisokat.

\section{Jegyzetek}

1 A rezidens orvosok más kategória, mint az általam vizsgált hallgatók, hiszen diplomázott, szakképzésüket elkezdett fiatalokról van szó. Köztük vannak a Marosvásárhelyi Orvosi és Gyógyszerészeti Egyetem azon végzettjei, akik Magyarországon kívánnak szakképesítést szerezni, viszont már elvándoroltak közülük azok, aki fejlettebb országban kívánnak szakorvosi címet nyerni. Így a kettő talán kiegyenlíti egymást. A migrációs szándékot jelző arányszám magas, tekintetbe véve azt is, hogy a migrációt komolyan tervezők egy része valószínűleg már kilépett ebből a csoportból.

2 A 2005-ös országos választásokat követően Eugen Nicolaescu miniszter egy interjúban arról számolt be, hogy tervezett reformjaikkal, melyek a rendszer átszervezését, az orvosi bérek növelését, a munkakörülmények javítását, az orvosokat megbecsülő bánásmódot tüzték ki célul, a kivándorlók számának csökkenését remélik elérni (Ion 2006).

3 Legalábbis kísérletet tesznek egy általános kép felvázolására, bár valamennyi kutató adathiányra panaszkodik. A hiányos adatok és gyakori feltételezések eltérő eredményekhez vezethetnek a különböző kutatásokban (Rohova 2011).

4 Összehasonlítási alapként viszont használhatóak, melyek segítségével megtudhatjuk, hogy vannak-e a magyarok migrációjának sajátosságai, hiszen a különböző strukturális feltételek többé-kevésbé azonosak a többségi és kisebbségi csoporthoz tartozók esetében. Ez a tanul- 
mány nem tér ki erre az összehasonlításra, hanem csak a magyar hallgatók migrációs potenciálját elemzi. Az összehasonlításról bővebben lásd: Pitó (2013).

A tanulmányban bemutatott kutatás előkészítésével és megvalósításával egy időben több más helyi és nemzetközi kutatás zajlott. Az egyik kifejezetten az általam is vizsgált egyetem végzettjeinek Magyarországra vándorlását dolgozza fel; jóval nagyobb időtávot foglal magában, de hiányoznak belőle a „friss” adatok, és csak az orvosok és fogorvosok migrációjára fókuszál (Ábrám 2011). Némely eredménye viszont ezt a kutatást is inspirálta.

Ez is csak az alapszakokra áll, az orvosi, a fogorvosi, a gyógyszerész, a nővér (egészségügyi asszisztens) és a szülész szakra. A fogászati asszisztens, balneológia és dietetika szakon az oktatás nyelve román (Ábrám 2011). Ez utóbbiakat viszont a kutatásban nem szerepeltettem.

A férfiak aránya alacsonyabb valamennyi szakterületen. A nővérek között a legkisebb az arányuk, 7-15\%, az orvostanhallgatók körében a legmagasabb: $37 \%$.

8 A kutatás a Diplomás Pályakövetési Rendszer keretében valósult meg 2012-ben. Az összehasonlításhoz a SOTE általános orvostudományi, egészségtudományi, fogorvos-tudományi és gyógyszerésztudományi karok hallgatóinak adatait használtam. A kutatás eredményeiről bővebben lásd: DPR (2013).

9 A gyorsjelentés felhívja a figyelmet arra, hogy ez az arányszám alacsonyabb, mint a korábbi években tapasztalt (EMK 2012). A román egészségügyi dolgozóknak ugyancsak fele szándékozott munkát vállalni külföldön az EU-csatlakozás évében (Rohova 2011).

10 Egy korábbi kutatás eredményei alapján a családi állapot hatása csak a hosszú távú külföldi munkavállalási szándék esetében volt szignifikáns: a nőtlenek-hajadonok, illetve az élettárssal élők a családosoknál nagyobb arányban tervezték ezt a típusú migrációt (Gödri, Kiss 2009).

11 A magyarországi hallgatók körében fordított sorrendet tapasztalunk: közel egyharmaduk bizonytalan terveiben - minden kar esetében -, legkevésbé az egészségtudományi kar hallgatói (32\%), leginkább pedig a fogorvostudományi kar hallgatói (59\%) szándékoznak külföldön munkát vállalni; a gyógyszerészhallgatók pedig az általánosorvostan-hallgatóknál kissé magasabb arányban.

A földrajzi és társadalmi mobilitás összekapcsolódása volt jellemző az Erdélyből érkezett bevándorlókra is (Gödri 2010). Ám vizsgálatomban az alacsony és magas státuszú családból jövők egyenlő mértékben tervezik a migrációt; a vegyes státuszúak kisebb arányban. A tisztított migrációs potenciál mondhatni egyforma mindhárom csoportban (49-53\%).

13 Az erdélyi magyar fiatalok között leginkább a diákok (68\%) és a kékgallérosok (szak-, betanított- és segédmunkások - 62\%) tervezik a külföldi munkavállalást; legkevésbé a vállalkozói vagy vezetői beosztással rendelkező és szellemi alkalmazotti réteg (47\%).

14 Kisebb arányban, de olyan esetek is előfordultak, amikor egyik vagy mindkét szülő felfelé vagy lefelé volt mobil (diszkrepancia volt iskolai végzettsége és foglalkozása között). Ilyen esetekben a foglalkozás szerint történt a besorolás.

15 A határozatlanok kizárásával, illetve a „tervezi - nem tervezi” dummy megalkotásával egymásnak ellentmondó eredményt hoz a kétféle szubjektív anyagi helyzet, jóllehet nem szignifikánsak az összefüggések. Az anyagi nehézségekkel küzdő családokban élők kissé nagyobb arányban tervezik a migrációt, mint a gondok nélkül élők (72\% a 67\%-kal szemben). Viszont az átlagos anyagi helyzettel bírók és a vagyonosak inkább szándékoznak külföldre menni, mint a szegények. Más migrációspotenciál-kutatás is megerősíti, hogy a vagyontalanság, a szubjektív szegénység csökkenti a külföldi munkavállalás esélyét, viszont a megélhetési gondok is ugyanilyen hatást fejtettek ki (Koltai, Sik 2012).

16 Az erdélyi magyar fiatalok által megjelölt célországok is hasonló rangsort követnek, azzal a különbséggel, hogy esetükben a skandináv országok megelőzik Magyarországot.

17 Ellenben a magyarországi hallgatók körében az idegennyelv-ismeret növeli a külföldi munkavállalási szándékot: pl. az angolul folyékonyan beszélők kétötöde (43\%) tervez külföldi munkavállalást, míg a gyenge nyelvismerettel rendelkezőknek csupán egynegyede (chi-négyzet: 43,653; szignifikanciasazint: 0,000). A bizonytalanokat kihagyva az elemzésből még hangsúlyosabbá válik a nyelvtudás hatása a migrációs tervekre.

18 Romániában egy rezidens orvos bére 800 RON (60 000 HUF) volt a megkérdezés időszakában. Az EU országai között a romániai egészségügyi dolgozók a második legalacsonyabban fizetettek (Reginato, Grosso 2011). 
19 Az alfejezet elemzései nem tartalmazzák a határozatlanokat, jóllehet közöttük is vannak olyanok (45\%), akik már szereztek be információkat a külföldi munkavállalásról.

20 A magyar állam retorikája nyíltan vállalta a határain túl élő magyarokkal való egységet, saját nemzete tagjaiként fogadva el őket (Fox 2003).

\section{Irodalom}

Ábrám Z. (2011): Az erdélyi magyar orvosmigráció újabb hullámai. Korunk, 4., 95-100.

Balázs P. (2003): Migráció a magyar orvostársadalomban és az 1989-es rendszerváltozás hatása. Egészségügyi Gazdasági Szemle, 4., 5-12.

Balogh Z. (2009): Tények a szakdolgozók migrációjáról. MESZK, 3., http://www.meszk.hu/upload/meszk/document/migracio_felmeres_200909.pdf?web_id= (Letöltés: 2013. március 7.)

Baukó M., Belicza É., Fodor M., Kullmann L., Miskovits E., Réthelyi J., Somogyvári Z., Szabó Gy., Tóth I. (2003): Humánerőforrás-hiány az egészségügyben - rövid vagy hosszú távú probléma? Egészségügyi Menedzsment, 4., 45-51.

Castles, S., Miller, M. J. (eds.) (2009): The age of migration. Palgrave Macmillan, London

Cehan, I., Teodorescu, C. (2012): Migrația personalului medical între responsabilitate socială și dreptul la liberă circulație. Revista Română de Bioetică, 4., 35-43. www.bioetica.ro/index.php/arhiva-bioetica/article/.../415

Coggi, P. T. (2011): Foreword. In: Wismar, M., Glinos, I., Maier, C., Palm, W., Figueras, J. (eds.): Health professional mobility and health systems. WHO, Copenhagen, ix.

Demuth, A. (2000): Some conceptual thoughts on migration research. In: Agozino, B. (ed.): Theoretical and methodological issues in migration research. Interdisciplinarity, intergenerational and international pesrpectives. Ashgate, Aldershot, 21-58.

DPR [Diplomás Pályakövető Rendszer] (2013): Hallgatók 2012. Kutatási zárótanulmány, Budapest. http://www.felvi.hu/pub_bin/dload/Hallgatok_2012_zarotanulmany.pdf. (Letöltés: 2014. június 25.)

Eke E., Girasek E., Szócska M. (2011): From melting pot to laboratory of change in Central Europe: Hungary and health workforce migration. In: Wismar. M., Glinos, I., Maier, C., Palm, W., Figueras, J. (eds.): Health professional mobility and health systems. WHO, Copenhagen, 365-394.

Eke J., Girasek E., Szócska M. (2009): A migráció a magyar orvosok körében. Statisztikai Szemle, 7-8., 795-827.

EMK [Egészségügyi Menedzserképző Központ] (2012): Az egészségügyi emberi erőforrásai. Felmérés a rezidens orvosok migrációs szándékairól, pályaválsztási terveikről és azok motivációs erőteréröl, 2012. Budapest. http://semmelweis.hu/emk/files/2007/11/2012rezidens_eredmenyek.pdf(Letöltés: 2014.július 2.)

Festinger, L. (szerk.) (2000): A kognitív disszonancia elmélete. Osiris, Budapest

Fox, J. (2003): National identities on the move: Transylvanian Hungarian labour migrants in Hungary. Journal of Ethnic and Migration Studies, 3., 449-466. http://doi.org/dp76ng

Glick Schiller, N., Basch, L., Szanton Blanc, C. (1995): From immigrant to transmigrant: Theorizing transnational migration. Anthropological Quarterly of UNH, 1., 48-63. http://doi.org/dcdt26

Glinos, I., Wismar, M., Maier, C., Palm, W., Figueras, J. (2011): Health professional mobility and health systems in Europe: 67 conclusions from the case-studies. In: Wismar, M., Glinos, I., Maier, C., Palm, W., Figueras, J. (eds.): Health professional mobility and health systems. WHO, Copenhagen, 67-86.

Gödri I. (2010): Bevándorlás és etnicitás - összefüggések nyomában. In: Hárs Á., Tóth J. (szerk.): Változó migráció - változó környezet. MTA Etnikai-nemzeti Kisebbségkutató Intézet, Budapest 87-124.

Gödri I., Kiss T. (2009): Migrációs hajlandóság, tervek és attitűdök az erdélyi magyarok körében. In: Spéder Zs. (szerk.): Kutatásjelentések 86. Párhuzamok. Anyaországi és erdélyi magyarok a századfordulón. KSH Népességtudományi Kutatóintézet, Budapest, 183-215.

Greco, G. (2010): International migration of health professionals: Towards a multidimensional framework for analysis and policy response. In: Shah, R. S. (ed.): The international migration of health workers: Ethics, rights and justice. Palgrave Macmillan, New York, 9-24. 
De Haas, H. (2011): The determinants of international migration. International Migration Institute, University of Oxford, Oxford. (Working Papers; 32.)

Horváth I. (2003): Migrációs hajlandóság az erdélyi magyarság körében - 2003 október. Erdélyi Társadalom, 2., 39-54.

Ion, C. (2006): Reperfuzia sistemului medical. http://www.presspromedic.ro/index.php? option=com_content\&task=view\&id=125\&Itemid=165 (Letöltés: 2006. április 4.)

Jakab Z. (2011): Foreword. In: Wismar, M., Maier, C. B., Glinos, I. A., Dussault, G., Figueras, J. (eds.): Health professional mobility and health systems. WHO, Copenhagen, xi.

Jenkins, R. Kydd, R., Mullen, P., Thomson, K., Sculley, J., Kuper, S., Carroll, J., Gureje, O., Hatcher, S., Brownie, S., Carroll, C., Hollins, S., Wong, M. L. (2010): International migration of doctors, and its impact on availability of psychiatrists in low and middle income countries. Plos one, 2, p.e9049. http://doi.org/fqm9xc

Kaelin, L. (2011): Care drain: the political making of health worker migration. Journal of Public Health Policy, 4., 489-498. http://doi.org/c9r7k5

Kiss T. (2012): Demográfiai körkép. A kisebbségi magyar közösségek demográfiai helyzete a Kárpátmedencében. Educatio, 1., 24-48.

Kiss T., Csata Zs. (2004): Migrációs-potenciál vizsgálatok Erdélyben. In: Kiss T. (szerk.): Népesedési folyamatok az ezredfordulón Erdélyben. Kriterion, Kolozsvár, 91-122.

Koltai J., Sik E. (2012): Határokon átnyúló munkaerő-piaci és jövedelemszerző mozgások a „végeken.” In: Kolosi T., Tóth I. Gy. (szerk.): Társadalmi Riport 2012. TÁRKI, Budapest, 209-226.

Lahav, G., Lavenex, S. (2013): International migration. In: Carlsnaes, W., Risse, T., Simmons, B. A. (eds.): Handbook of international relations. Sage Publications, London, 746-775. http://doi.org/6fn

Lavenex, S. (2008): The competition state and multilateral liberalization of highly skilled migration. In: Smith, M. P., Favell, A. (eds.): The human face of global mobility: International highly skilled migration in Europe, North America and the Asia-Pacific. Transaction Publishers, New Brunswick, 29-52.

Levatino, A., Pecoud, A. (2012): Overcoming the ethical dilemmas of skilled migration? An analysis of international narratives on the "brain drain." American Behavioral Scientist, 9., 1258-1276. http://doi.org/6fp

Maier, C. B., Glinos, I., Wismar, M., Bremner, J., Dussault, G., Figueras, J. (2011): Cross-country analysis of health professional mobility in Europe: The results. In: Wismar, M., Glinos, I., Maier, C., Palm, W., Figueras, J. (eds.): Health professional mobility and health systems. WHO, Copenhagen, 23-66.

Massey, D. S. (1999): Why does immigration occur? A theoretical synthesis. In: Hirschman, C. , Kasinitz, P., Dewind, J. (eds.): The handbook of international migration. Russel Sage Foundation, 34-52.

Massey, D. S., Arango, J., Hugo, G., Kouaouci, A., Pellegrino, A., Taylor, J. (1993): Theories of international migration: A review and appraisal. Population and Development Review, 3., 431-466. http://doi.org/fpbvf4

Melegh A. (2012): Net migration and historical development in Southeastern Europe since 1950. Hungarian Historical Review, 3-4., 415-453.

Messina, A. M., Lahav, G. (eds.) (2006): The migration reader. Exploring politics and policies. Lynne Rienner Publishers, London

NKI [Nemzeti Kisebbségkutató Intézet] (2013): Erdélyi magyarok a romániai és a magyarországi politikai térben. Kolozsvár.

Örkény A. (2003): A migrációs potenciál szociodemográfiai okai a Kárpát-medencei magyarok körében. In: Örkény A. (szerk.): Menni vagy maradni? Kedvezménytörvény és migrációs várakozások. MTA Politikatudományok Intézete, Budapest, 150-187.

Pitó K. (2015): Migration potential of graduates in a medical school in Romania. A qualitative approach. Corvinus Journal of Sociology and Social Policy, 1., 129-151. http://doi.org/6fq

Pitó K. (2013): A Marosvásárhelyi Orvosi és Gyógyszerészeti Egyetem migrációs potenciálja. In: Koncz I., Nagy E. (szerk.): Tudományos próbapálya. Professzorok az Európai Magyarországért Egyesület, Budapest, 68-78.

Portes, A. (1995): Economic sociology and the sociology of immigration: A conceptual overview. In: Portes, A. (ed.): The economic sociology of immigration. Essays on networks, ethnicity, and enterpreneurship. Russel Sage Foundation, New York, 1-41.

Portes, A. (1998): Social capital: Its origins and applications in modern sociology. Annual Review of Sociology, 1., 1-24. http://doi.org/cmmcsz 
Portes, A., Böröcz J. (1989): Contemporary immigration: Theoretical perspectives on its determinants and modes of incorporation. International Migration Review, 3., 606-626. http://doi.org/dcbqmc

Portes, A., Böröcz J. (2001): Keserű kenyér: a munkaerő nemzetközi migrációjának szociológiai problémái. In: Sik E. (szerk.): A migráció szociológiája. Szociális és Családügyi Minisztérium, Budapest, 69-87.

Reginato, E., Grosso, R. (2011): European hospital doctors' salaries http://www.liganet.hu/news/6205/F11071_EN_European_Hospital_Doctors_Salaries.pdf (Letöltés: 2015.június 20.)

Roberts, B. R. (1995): Socially expected durations and the economic adjustment of immigrants. In: Portes, A. (ed.): The economic sociology of immigration. Essays on networks, ethnicity, and enterpreneurship. Russel Sage Foundation, New York, 42-86.

Rohova, M. (2011): Romania. Mobility of health professionals. Medical University of Varna, Varna. http://www.mohprof.eu/LIVE/DATA/National_reports/national_report_Romania.pdf (Letöltés: 2013. november 12.)

Sassen, S. (1995): Immigration and local labor markets. In: Portes, A. (ed.): The economic sociology of immigration: Essays on networks, ethnicity, and entrepreneurship. Russel Sage Foundation, New York, 87-127.

Sassen, S. (ed.) (2007): Sociology of globalization. W. W. Norton, New York

Sik E. (2003): A migrációs potenciál kutatásának alapfogalmai. In: Örkény A. (szerk.): Menni vagy maradni? Kedvezménytörvény és migrációs várakozások. MTA Politikatudományok Intézete, Budapest, 15-18.

Sik E., Örkény A. (2003): A migrációs potenciál kialakulásának mechanizmusai. In: Örkény A. (szerk.): Menni vagy maradni? Kedvezménytörvény és migrációs várakozások. MTA Politikatudományok Intézete, Budapest, 188-200.

Sik E., Simonovits B. (2003): A migrációs potenciál mértéke és társadalmi bázisa a Kárpát-medencei magyarok körében. In: Örkény A. (szerk.): Menni vagy maradni? Kedvezménytörvény és migrációs várakozások. MTA Politikatudományok Intézete, Budapest, 43-66.

Simonovits B. (2003): A migrációs burok hatása a migrációs potenciálra a Kárpát-medencei magyarok körében. In: Örkény A. (szerk.): Menni vagy maradni? Kedvezménytörvény és migrációs várakozások. MTA Politikatudományok Intézete, Budapest, 143-149.

Tilly, C. (2001): Áthelyeződött hálózatok. In: Sik E. (szerk.): A migráció szociológiája. Szociális és Családügyi Minisztérium, Budapest, 89-103.

Tóth P. P. (2004): Egy évtized után. Kisebbségkutatás, 4., 598-626.

Vízvári L. (2003): „Népvándorlás” a 21. században az egészségügyi dolgozók körében. Egészségügyi Gazdasági Szemle, 1-2., 38-41. 